\title{
Authentic Learning: Enhancing Learners' Academic Literacy Skills
}

\author{
Albert Agbesi Wornyo $^{1 *}$, Ernest Kwesi Klu², Hlaviso Motlhaka ${ }^{2}$ \\ ${ }^{1}$ University of Education, Winneba, Ghana \\ ${ }^{2}$ Department of English, University of Venda, South Africa
}

Corresponding Author: Albert Agbesi Wornyo, E-mail : awornyo@yahoo.com

\begin{tabular}{l} 
ARTICLE INFO \\
\hline Article history \\
Received: January 22, 2018 \\
Accepted: March 17, 2018 \\
Published: July 01, 2018 \\
Volume: $7 \quad$ Issue: 4 \\
Advance access: May 2018 \\
\hline
\end{tabular}

Conflicts of interest: None Funding: None

\begin{abstract}
Several studies have shown that authentic learning facilitates learners' acquisition of knowledge, understanding of concepts and application of skills to solve real life problems. This study explores how authentic learning can be used to help English as a Second Language (ESL) learners to acquire academic literacy skills. The objective of the study was to observe students' reaction to authentic learning, to find out their learning styles and to find out their views about the authentic learning tasks and activities. The study adopted observation and a qualitative free text comments approach to collect data about students' reaction to the authentic learning activities and students' learning styles. In addition, focus group discussions and interviews were conducted to let students express their views about the authentic learning tasks and activities that were implemented. The paper presents the views of students about the authentic learning tasks and activities that were implemented. The students reacted positively to the authentic learning tasks and activities and expressed satisfaction. The findings of the study demonstrate that authentic learning can be used to enhance the academic literacy skills of ESL learners.
\end{abstract}

Key words: Academic Literacy, Academic Presentations, Authentic Learning, Collaboration, Learning Styles

\section{INTRODUCTION}

It is a widely held opinion among educators that learning is best accomplished through experiences by doing rather than listening and observation. Research in education and training has proven this fact (Pearce, 2016). However the hindrance to the implementation of learning by doing is that it has not been easy to adopt this kind of learning especially in the formal educational system. Researchers and educators have tried several ways to turn instruction in the classroom into series of tasks and activities that will serve as learning experiences for learners. One of such ways of making students learn by doing rather than listening is through authentic learning tasks and activities.

Authentic learning is learning by solving real-world problems. The definitions of authentic learning emphasises learning by exposure to real-world experiences. Lombardi (2007, p. 2) defines authentic learning "as a type of learning that focuses on real-world, complex problems and their solutions, using role-playing exercises, problem-based activities, case studies and participation in virtual communities of practice." Har (2016, p. 2) defines it as "a means of learning which happens by actually participating and working on real-world problems." Pearce (2016, p. 1) defines authentic learning as "learning designed to connect what students are taught in school to real-world issues, problems, and applica- tions; learning experiences that mirror the complexities and ambiguities of real life." Authentic learning is designed in such a way that students are exposed to real life experiences of what they are being taught.

Har (2016, p. 2) traces the history of authentic learning to the early " $16^{\text {th }}$ Century when Descartes proposed the idea of authenticity as following a moral inner voice." According to him, this idea was later expanded by Philosopher Rousseau and further developed by Philosopher Herder to mean how we discover our identity through our experiences. So, authentic learning is simply the acquisition of knowledge through the experiences that we go through.

Why should students be taken through authentic learning? Authentic learning exposes students to the reality of everyday life. In our everyday lives, we are confronted with unexpected situations and we make adjustments and try to adapt to the circumstances in which we find ourselves (Pearce, 2016). This is the reality of life. Formal instruction in the classroom seems to create the impression that life is highly organized and follows steps laid down in uninterrupted manner. Authentic learning reflects how we go through life experiences by utilizing our knowledge and experiences to decide the steps or actions that we have to take on the spot.

In addition, authentic learning has great advantages over learning by listening. It gives students the opportunity 
to attain all the three goals of learning: acquisition of skill, understanding of concepts and the application of knowledge. Learners are able to do whatever they are supposed to learn better when they are given the opportunity to take part in doing what they are supposed to acquire rather than when they are told how it is done. Also, authentic learning facilitates understanding; meaning is constructed. We do not understand something by being told what the thing is. In addition, classroom learning is not easily transferred because there is a disconnection between the knowledge acquired and the situations and instances where it is applicable. Authentic learning therefore enables learners to transfer what is learnt to appropriate situations because the acquisition of the knowledge takes place in situations where they are applicable. This enables students to use the skills and knowledge they have acquired in practical situations to solve problems that confront them. It makes the application of skill and knowledge easy.

Traditional formal instruction is restricted to the walls of the classroom and therefore monotonous and boring. Authentic learning is carried out often outside the classroom and may take learners to several different environments. It therefore facilitates active participation and the boredom associated with the classroom is avoided. In addition, it breaks down the power hierarchy in the classroom situation making both teachers and learners active participants in the discovery of knowledge.

Authentic learning is now used in the $21^{\text {st }}$ Century especially through e-learning as a result of technological advancement to help improve students' performance and satisfaction in higher education. Hui and Koplin (2011) demonstrated how authentic assessment tasks performed by students through e-learning in a finance course enabled the students to connect their classroom learning to the outside world. A survey was conducted in South African universities to find out how educators in higher learning incorporate authentic learning in their teaching. The findings revealed that educators in higher learning in South Africa incorporate elements of authentic learning in their teaching at various degrees. It was however found out that assessment was the area that authentic activities were least used. This was attributed to how assessment in higher education in South Africa is based on traditional examination (Bozalek et al, 2013). Simpson (2016) measured the success rate of students after introducing authentic learning methods into the course of Masters in Business Administration students. The result showed that there was improvement in the pass rate of students and the students expressed great satisfaction in the method of learning. Lock and Duggleby (2017) used the Internet as a global classroom to facilitate authentic learning of Social Studies. The report indicates that "when students in Social Studies are engaged in authentic learning that uses a global classroom approach, it influences how they see themselves as global citizens" (p. 21).

Although authentic learning tasks and activities have been incorporated in higher learning, most of the studies that have reported their implementation show that authentic tasks and activities have been implemented in the teaching of courses in the Sciences and subject areas that require the manipulation of tools, objects and software applications. It seems there are few studies that have explored the implementation of authentic learning tasks and activities in the teaching of language skills in higher education. One of such a study is Fitzsimmons (2006) who argues that Literature is a form of authentic learning and suggests that assessment in Literature should adopt some principles of authentic learning. This is an indication that authentic learning tasks and activities can be used to enhance learners' language skills; hence the implementation of authentic learning tasks and activities in this study to explore their applicability to the teaching of academic writing skills.

On the basis of the numerous successes of authentic learning in improving students' performance and satisfaction, this study seeks to explore students' views about authentic learning by incorporating authentic learning elements in the teaching of academic literacy skills to ESL first year students in higher learning. The aim of this study therefore was to explore ESL students' reaction to authentic learning tasks and activities in academic literacy skills. The focus of the study was to find out the views of the students about authentic learning tasks and activities relevant to academic literacy skills and to find out the learning styles that learners use.

The teaching of academic literacy; specifically, the teaching of in-text citation and referencing is a skill that is novel to learners who get enrolled in higher education. This skill is necessary for all ESL students to acquire for them to be able to meet the academic requirements of their various disciplines. Learners in higher education need this skill in order to be able to write term papers, proposals, reports of their experiments and project works and finally to write their thesis or dissertation as requirements for graduation. Learners find it difficult to grasp this skill. This shows in their term papers, dissertations and thesis. In some cases, students who have passed their course works fail in writing good long essays, project works or thesis and therefore fail to graduate. Some professors get disgusted with students' thesis and project works that they supervise. Students often express their frustration when they receive feedback from their supervisors about how their sources have been poorly cited and references not properly written. This problem needs to be addressed to reduce the frustration of both supervisors and students.

\section{Research Questions}

The research questions of the study are:

- How will students react to the use of authentic learning tasks and activities in the academic literacy classroom and outside the classroom?

- What are the learning styles used by students?

- What are students' views about authentic learning tasks and activities in the classroom and outside the classroom?

\section{Significance of the Study}

This study is useful to lecturers and instructors involved in the teaching of academic literacy in ESL/EFL settings all over the world. It is very useful to English for Academic Purpose (EAP) pedagogy and to researchers and practitioners in the field of EAP. 


\section{LITERATURE REVIEW}

The theoretical foundation of authentic learning is the constructivists view of learning based on the belief that learning is not passed on to the learner in a passive manner but requires the learner's active participation in the learning process. This belief was projected by the cognitive psychologists such as Piaget (1999) and Vygotsky (1980) who emphasized the learners' participation in a sociocultural environment that encourages step by step development through the support of an experienced person (Zualkerman, 2006). The design of authentic learning fits within this broad theoretical approach to teaching and learning.

According to Zualkerman (2006, p. 200) authentic learning environment is "a learning curriculum" that provides "a set of situated opportunities" to facilitate adaptation for the learner to attain a high degree of fit within the task environment. The design of an authentic learning environment provides the appropriate set of situated opportunities. Zualkerman (2006) states four components of the situated opportunities. These components are the provision of the right physical environment with the right information, giving the appropriate tasks, activating the required cognitive constraints and learning style of the learner and attaining the desired goals and intentions. When this is done, it leads to the right adaptation of the learner to fit within the professional or work environment.

The theoretical basis of authentic learning is that when learners are exposed to the complexities of the task and the working environment they are being trained to function, it prepares them to fit within the working environment after training. Saxena (2013) points this out clearly by stating that:

By confronting students with uncertainty, ambiguity and conflicting perspectives, educators can help them mature their thinking and make them able to use problem-solving approaches effectively. To be competitive in the global job market, students must become comfortable with the complexities of real-world problems.

Authentic learning is a departure from the traditional method of teaching where knowledge is delivered in a passive manner. The use of authentic tasks and activities in teaching challenges learners by presenting them with problem-solving situations. Such situations impose the right cognitive constraints on the learners. For example, Brown (1997) explains the what, how and where of learning by pointing out that the what of learning is about the content and the how and where of learning are the situation and the collaborative culture and argues that the learning classrooms should be turned into learning communities where learners are actively involved in solving real-life problems. Brophy and Alleman (1991) call for attention to be directed toward tasks and activities that offer learners the opportunity to acquire knowledge in a way that enables them to integrate and apply the skills and knowledge acquired to achieve the desired goals of the curriculum. Herrington and Oliver (2000) argue that much of the abstract knowledge that learners acquire in the classroom is not retrievable in real-life situations to solve real-life problems. They propose authentic situational learning as an alternative pedagogical framework for instruction in schools and universities.
Authentic learning tasks and activities are highly recommended for teaching in higher education. Learners in higher education are adults who are being trained for the job market. Authentic learning tasks and activities put learners in real-world learning situations which are mainly tasks performed on the job and at the work places. For this reason, authentic learning tasks and activities are being implemented in institutions of higher learning. Koenders (2006) reports how authentic online learning in Biology enhanced the learning experiences of the learners. Kuldell (2007) also demonstrates the learning of Synthetic Biology using authentic teaching and learning activities. Meyer and Nulty (2009) demonstrate how authentic learning tasks and activities can be incorporated in the curriculum of environmental and ecological science students.

Advancement in information and communication technologies (ICTs) and their applications through the use of the Internet is making the implementation of authentic learning tasks and activities in higher education popular. Herrington and Reeve (2003) suggest that there is the need to continue to explore and design curriculum in higher learning to integrate online tasks and activities for training in higher education to be relevant to job and career opportunities. Bennet, Agostinho and Lockyer (2005) suggest the application of ICTs to learning designs in higher education. To facilitate the implementation of authentic learning, Oliver, Herrington and Reeves (2011) discuss how the affordability of Internet technologies can facilitate the implementation of authentic learning tasks and activities in online courses.

\section{METHOD}

\section{Population and Sampling}

First year undergraduate students offering the English Communication Skills course in two ESL settings of Ghana and South Africa constitute the population for the study. For the ESL setting of Ghana, first year students of the 2016/2017 Academic Year in the Department of Mathematics and Physics Education of the University of Education, Winneba were used for the study. A total of 274 (Two hundred and seventy-four) students were enrolled for the Communication Skills course in the Department of Mathematics and Physics Education; 222 students for Mathematics Education and 52 students for Physics Education. For the ESL setting of South Africa, first year students of the 2016 Academic Year in the School of Human and Social Sciences of the University of Venda who offered the English Communication Skills course were used for the study. The students in both settings were taken through the authentic learning tasks and activities. All students enrolled for the course participated in the authentic learning tasks and activities. There were two focus group discussions and interviews in both settings. Five students constitute one focus group. There were two focus group discussions and interviews in each of the two ESL settings; making a total of four focus group discussions and interviews. In all, twenty students took part in the focus group discussions and interviews. Random sampling was used to select the twenty students for the focus group discussions and interviews. 


\section{Data Collection and Instruments}

Data collection was carried out between August and December 2016. This period forms the semester within which the study was conducted. The contact hours were three hours a week for a period of thirteen weeks. Data collection was in the form of the observation of the participants such as their behavior, their reaction to the tasks and activities, and their response to questions and instructions. The instructors carried out the observations themselves; so the observations were in the form of participant observation since the instructors of the course using authentic learning tasks and activities were part of the teaching and learning process. In addition to the observations carried out by the instructors using their observation check list, further data were collected through open ended questionnaires. At the end of the course in both settings, all the participants were given open-ended questionnaires to respond to in the form of providing free qualitative comments. For example, students were asked to indicate their views on the visual, audio and audio-visual materials on how to structure academic papers and write references. There were two focus group discussions and interviews in each setting to gather further information about students' view on the authentic learning tasks and activities. In the focus group discussions and interviews, the students expressed their views on the tasks and activities that they were taken through and shared their learning experiences with the instructors.

\section{Procedure}

This is a qualitative research that explored the views of the participants about authentic learning tasks and activities in the academic literacy course. The study adopted seven elements of authentic learning. The conduct of authentic learning studies is guided by a number of elements that constitute authentic learning. Lombardi (2007, p. 3) proposes ten elements of authentic learning. These include tasks and activities that have "real world relevance, ill-defined problems, sustained investigation, multiple sources and perspective, collaboration, reflection, interdisciplinary perspectives, integrated assessment, polished products and multiple interpretations and outcomes." Herrington, Reeves and Oliver (2010) propose nine elements of authentic learning. These elements are authentic context, authentic task, expert performance, multiple perspective, collaboration, reflection, articulation, coaching, and scaffolding and assessment. The elements proposed by Herrintong et al. (2010) confirm the elements proposed by Lombardi (2007).

Putting the elements of authentic learning together, this study adopted seven of the elements of authentic learning. The seven elements of authentic learning adopted for this study were:

- Authentic context/real-world relevance: Students were exposed to authentic contexts of academic literacy in various forms. The students attended faculty seminars and took part in the presentation of academic papers. Two lecture hours were turned into seminar presentations. The students were taken to the library and they picked journals relevant to their disciplines to observe the different styles of referencing such as the Harvard style, the APA style and the MLA style and to paraphrase and summarize some of the articles in the journals. Students were directed and guided to visit academic journals sites online to download and study articles relevant to their disciplines. Students were taken through how to submit papers online and how to submit papers by email attachment. WhatsApp platforms were created to facilitate the sharing of information (visual, audio, audio-visual etc.) related to academic literacy and for group discussions to continue after class meetings and seminars.

- Authentic tasks/ill-defined problems: The authentic tasks given to students to acquaint them with academic literacy skills included individual and group power point presentations at seminars. Students were put in groups to write concept papers. Each student was required to write a concept paper to be submitted as e-mail attachment.

- Collaboration: Students wrote concept papers in groups. Students presented papers in groups at seminars. Students visited the library in groups to access journals in their disciplines under the guidance of their instructors. Students accessed journals online in groups. Students engaged in discussions in groups.

- Reflection: Students were given the opportunity to choose their own topics for the individual as well as the group concept papers that they were asked to write. This enabled them to reflect on their learning and make their own decisions both individually and as a group. All the students were given the opportunity to give qualitative open-ended free text comments as a form of evaluating the course as well as collecting data for the study. Some of the students took part in a focus group discussion and interview.

- Multiple sources and perspective: Students from broad disciplines but different specific departments were put together to work on one concept paper. For example, some students from the Department of Mathematics and the Department of Physics were put together to work as a group. Students contributed to the topic chosen from their disciplinary perspectives as well as from the perspectives of other disciplines, encouraging thinking in diverse perspectives as they have to work together.

- Coaching and scaffolding: In all the tasks and activities in which students participated, guidance was provided in the form of clarifying what students did not understand, answering the questions that the students asked and providing individual consultations as well as group consultations to direct students to the skills expected to be acquired. The seminar presentations were supervised and questions that were asked were answered. The online access of journals as well as the visits to the library to access hard copies of journals were regulated and assistance given to the students. Moreover, feedback was provided in the form of audio recordings that were posted onto the WhatsApp platforms.

- Integrated assessment: Students continuous assessment was based on the authentic tasks they participated in. 
The assessment scores were allocated to the group concept papers, individual concept papers, group presentations and individual presentations.

\section{ANALYSIS AND FINDINGS}

Data collected from the observation, the open ended questionnaires that were administered and the focus group discussions and focus group interviews were recorded and the discussions and interviews were transcribed. The data collected were analyzed following the objectives of the study as presented below.

\section{Reaction of Students}

From the observation carried out, students' reaction to the authentic tasks and activities was positive. The students were enthusiastic about the various tasks and activities. The visit to the library to access hard copies of journals and the online search for journal were fascinating to students. The students now go online on their own to look for materials not only on the topics on which they wrote their concept papers, but to look for additional information online on topics that they are taught. Class discussions and discussions held after seminar presentations were lively and healthy. There were instances that some students disagree with others over certain assertions and conclusions drawn. The search of journals online led to some students getting access to formats and citation of sources not discussed in class and some of these issues led to disagreement among some of the students making class discussions lively with active participation leading to further searches in some cases for such issues of disagreement to be resolved.

\section{Learning Styles used by Students}

Learning styles are the various means by which learners use their senses for the intake of information and comprehension of new information. There are several learning styles and learners vary in their use of learning styles. Some learners are visual learners, others are aural learners, some are read/ write learners and some are kinesthetic learners. In addition, some learners are also classified as tactile learners, group learners and individual learners. The study confirms that ESL learners vary in their learning styles. Students' response to the means by which they are able to learn better shows that the learners vary greatly in their learning styles. It was found out that some learners are visual learners. These learners tend to enjoy the videos, charts, and diagrams on academic writing and academic presentations that were shared on the WhatsApp platforms. They also enjoyed learning from the power point presentations that were done at the seminars. Some of the students indicated that they enjoyed the audio feedback posted on the WhatsApp platforms by the instructors. They also found the group discussions and power point presentations very useful for their learning. These students could be said to be auditory/aural learners. What some of the students indicated that they learnt from most was their participation in the preparation of the power point slides that offered them the opportunity to have their hands on in organizing and arranging materials for the power point presentations. These are students who could be classified as kinesthetic and tactile learners.

\section{Students' Views}

The comments of students gathered from the open ended questionnaires and the focus group discussions and interviews, indicated great satisfaction in the authentic tasks and activities in which they participated. Some of the students expressed their delight and the great benefits they derived from the authentic tasks that were carried out. The students' were of the view that the authentic academic literacy learning offered them the opportunity to gain deep insight into the topics that were chosen for their group work and individual concept papers and seminar presentations. According to the students, because they were required to consult multiple sources and cite these sources in the concept papers that they wrote, this compelled them to read deeply to understand the topics before they were able to paraphrase the sources and cite them in their papers. Moreover, the authentic task of writing concept papers on their chosen topics required them to read widely as they were required to cite at least ten sources in their papers. This helped to broaden their scope and knowledge and understanding of the topics chosen for their term papers.

The students indicated that the power point seminar presentations were not easy tasks for some of them. Some of the students revealed that they were 'shaking' during their presentations. Some students indicated that the power point presentation which was done on group basis was better for them as they worked in group and had others to support them in the presentation and answering of questions. The students however expressed great satisfaction for the opportunity to stand in front of people to do their presentations. They indicated that this experience has boosted their confidence.

\section{DISCUSSIONS AND CONCLUSIONS}

The authentic learning tasks implemented provided the opportunity to introduce interesting and challenging tasks in the ESL class. The reaction of students and the views they expressed clearly indicated how the tasks and activities that they performed sustained their interest throughout the course. The authentic learning tasks are challenging and encourage active participation and the eagerness of the students to live up to the demands of the tasks given. The demands of the tasks served as catalyst that propelled the students into action and made them poised to learn. This made the students to be able to learn on their own to find answers to some of the inconsistencies they came across and they were able to resolve the ambiguities embedded in some of the tasks. For example, as students were given the task to write concept papers, they were compelled to read articles and materials relevant to the topic they were writing about and this helped improve students' academic literacy skill by improving on their skill of gathering information from various sources and conducting a critical reading to write a literature review. 
It is evident that authentic learning encourages collaboration. Some of the tasks given were group work. This encouraged collaboration and team work among the students. Apart from the group work that required team work and collaboration, the demands of the tasks in general made students consult one another to get clarification on things that they could not grasp readily. As a result of this, there were group discussions and collaborations beyond the groups that were formed for the purpose of the tasks given. This is a good and healthy attitude to be cultivated in students. Authentic learning activities therefore enable learners to acquire social collaboration skills as they work together with their colleagues and peers.

The traditional style of teaching through the delivery of lectures in the lecture halls is less effective in helping learners acquire knowledge. It is less effective because it is restrictive in the scope of learning styles that it offers. Several studies have shown that learners vary in the senses that they use most to understand, organize and retain experiences (Kinsella, 1995; Oxford, 1995; Reid, 1987; Reid, 1995). Montgomery and Groat (1998) call for the need to vary teaching styles to meet the different learning styles of learners. Oxford (2003) points out that a single method of teaching does not meet the learners' different styles and Kara (2009) points out that often, there is a mismatch between teaching styles and learners learning styles and calls for a balanced teaching style. According to Fleming (2012), teaching should cover the senses by which we take information and give out information. He advocates instruction that covers four learning styles: Visual, Aural, Read/Write and Kinesthetic (VARK). Authentic learning tasks and activities cover all these learning styles and are therefore suitable for addressing the different learning styles of all learners.

The study concludes that students are able to acquire academic literacy skills better in an authentic learning environment. Authentic learning tasks and activities appeal to the various senses that we use for the intake of information and are able to satisfy the various learning styles of learners. Students find it fascinating to be involved in performing authentic tasks like academic presentations at seminars. The authentic learning tasks and activities undertaken exposed both learners and instructors to great learning experiences that have enhanced the academic literacy skills of both instructors and learners.

\section{REFERENCES}

Bennet, S., Agostinho, S. \& Lockyer, L. (2005). Reusable learning designs in university education. In T.C. Montgomerie \& J. R. Parker (Eds.), Proceedings of the IASTED International Conference on Education and Technology (pp. 102-106). Anaheim, CA: ACTA Press.

Bozalek, V., Gachogo, D., Alexander, L., Watters, K., Wood, D. Ivala, E. \& Herrington, J. (2013). The use of emerging technologies for authentic learning: A South African study in higher education. British Journal of Educational Technology, 44(4), 629-638.

Brophy, J. \& Allema, J. (1991). Activities as instructional tools: A framework for analysis and evaluation. Educational Researcher. 20, 9-23.
Brown, A. L. (1997). Transforming schools into communities of thinking and learning about serious matters. American Psychologist, 52(4), 399-413.

Fitzsimmons, J. (2006). Speaking snake: Authentic learning and the study of literature. In A. Herrington \& J. Herrington (Eds.), Authentic learning environments in higher education (pp. 162-171). Hershey, PA: Information Science Publishing.

Fleming, N.D. (2012). Teaching and learning style: VARK Strategies. Springfield: Author.

Har, L. B. (2013). Authentic learning. Hong Kong: The Hong Kong Institute of Education. Retrieved from www.ied. edu.hk/aclass/.

Herrington, J. \& Oliver, R. ((2000). An instructional design framework for authentic learning environments. Educational Technology Research and Technology. 48(3), 23-48.

Herrington, J., Oliver, R. \& Reeves, T.C. (2003). Patterns of engagement in authentic online learning environments. Australian Journal of Educational Technology, 19(1), 59-71.

Herrington, J., Reeves, T.C. \& Oliver, R. (2010). A guide to authentic e-Learning. New York: Routledge.

Hui, F. \& Koplin, M. (2011). The implementation of authentic activities for learning: A case study in finance education. e-Journal of Business Education and Scholarship of Teaching, 5(1), 59-72.

Kara, S. (2009). Learning Styles and Teaching Styles: A Case Study in Foreign Language Classroom. Conference of the International Journal of Arts and Sciences. 1(20), 77-82.

Kinsella, K. (1995). Understanding and empowering diverse learners in ESL classrooms. In J.M. Reid (Ed.), Learning Styles in the ESL/EFL Classroom (pp. 170-194). New York: Heinle and Heinle Publishers.

Koenders, A. (2006). An authentic online learning environment in university introductory biology. In J. Herrington \& T. Herrington (Eds.). Authentic learning environment in higher education (pp. 48-60). Hershey, PA: Information Science Publishing.

Kuldell, N. (2007). Authentic teaching and learning through synthetic biology. Journal of Biological Engineering, $1(1), 8-21$.

Lock, J. \& Duggleby, S. (2017). Authentic earning in the social studies classroom: Connecting globally. One World in Dialogue, 4(1), 20-27.

Lombardi, M. M. (2007). Authentic learning for the $21^{\text {st }}$ Century: An overview. In D. G. Oblinger (Ed.), Educause learning initiative: Advancing learning through IT innovation (pp.1-12). Boulder, CO: Educause Learning.

Meyer, N., \& Nulty, D. (2009). How to use (five) curriculum design principles to align authentic learning environments, assessment, students' approaches to thinking and learning outcomes. Assessment and Evaluation in Higher Education, 34(5), 565-577.

Montgomery, S. \& Groat, L.N. (1998). Student learning styles and their implications for teaching. The Centre for Learning and Teaching, 10, 1-6. 
Oliver, R., Herrington, J. \& Reeves T. (2011). Authentic activities and online learning. Research Online: ECU Publications Press.

Oxford, R. L. (1995). Gender differences in language learning styles: What do they mean? In J.M. Reid (ed.), Learning styles in ESL/EFL classroom (pp.34-46). New York: Heinle and Heinle Publishers.

Oxford, R. L. (2003). Learning styles and strategies: An overview. GALA, 1-25.

Pearce, S. (2016). Authentic learning: What, why and how? e-Teaching Management Strategies for the Classroom. Retrieved from http://www.rethink.edu.org.

Piaget, J. (1999). The Construction of Reality in the Child. New York: Routledge.

Reid, J. M. (1987). The learning style preferences of ESL students. TESOL Quarterly, 2 (1), 87-111.
Reid, J. M. (Ed) (1995). Preface. In J.M. Reid (Ed.), Learning styles in ESL/EFL classroom (pp. vii-xvii). New York: Heinle and Heinle Publishers.

Saxena, S. (2013). How technology can support authentic learning. EdTechReview. Retrieved from http://edtechreview.in/news/865-how-technology-can-support-authentic-learning.

Simpson, J. (2016). Authentic learning - Does it improve pass rates and student satisfaction? Journal of Perspectives in Applied Academic Practice, 4(2), 62-70.

Vygotsky, L.S. (1980). Mind in society: The development of higher psychological processes. Cambridge, MA: Harvard University Press.

Zualkerman, I. A. (2006). A framework and a methodology for developing authentic constructivist e-Learning environments. Educational Technology Society, 9(2), 198-212. 